\title{
G Protein-Coupled Estrogen Receptor: Rapid Effects on Hippocampal-Dependent Spatial Memory and Synaptic Plasticity
}

\author{
Ashok Kumar* and Thomas C. Foster \\ Department of Neuroscience, McKnight Brain Institute, University of Florida, Gainesville, FL, United States
}

\section{OPEN ACCESS}

Edited by:

Marilena Kampa,

University of Crete, Greece

Reviewed by:

Richard T. Premont,

Harrington Discovery Institute,

United States

Sylvie Claeysen

Institut National de la Santé et de la

Recherche Médicale

(INSERM), France

${ }^{*}$ Correspondence: Ashok Kumar kash@ufl.edu

Specialty section

This article was submitted to Molecular and Structural Endocrinology

a section of the journal Frontiers in Endocrinology

Received: 01 April 2020 Accepted: 14 May 2020

Published: 10 June 2020

Citation:

Kumar A and Foster TC (2020) G Protein-Coupled Estrogen Receptor:

Rapid Effects on Hippocampal-Dependent Spatial Memory and Synaptic Plasticity. Front. Endocrinol. 11:385 doi: $10.3389 /$ fendo.2020.00385
In the hippocampus, estrogen regulates gene transcription linked to neuronal growth, neuroprotection, and the maintenance of memory function (1-3). The mechanism is likely to involve genomic regulation through classic estrogen receptor (ER) signaling cascades that influence transcription. Estrogens binding to classic nuclear ERs, alpha $(E R \alpha)$ and beta $(E R \beta)$, and have pleotropic effects on development, behavior, and neurophysiological functions, including synaptic plasticity and memory consolidation $(4-7)$. In addition to $E R \alpha$ and $E R \beta$, estrogen can also initiate activation of classical second messenger signaling cascades to influence the activity of G-proteins and a host of kinases, resulting in rapid changes in physiology (8-14). These rapid effects of estrogen are commonly mediated by membrane receptors. In the late 90 s, multiple laboratories cloned cDNA/gene for an orphan G-protein-coupled receptor with very low homology with other G-protein-coupled receptors and named it G-protein-coupled receptor 30 (GPR30) (15-20). Later in 2007, the International Union of Basic and Clinical Pharmacology designated GPR30 as G protein-coupled estrogen receptor (GPER) (21); GPER is a seven-transmembrane G-protein-coupled receptor, predominantly expressed on the cell membrane (22). Interestingly, GPER is reported to mediate many of the rapid responses of estradiol in the adult brain, and is widely distributed in the mammalian brain including the plasma membrane of hippocampal neurons (23-31). GPER modulates second messenger signaling cascades involving $G \alpha_{S^{-}}$and $G \alpha_{i / 0}$-associated increase in cyclic adenosine monophosphate and phosphoinositide 3-kinase or Src protein kinase respectively $(32,33)$. Activation of GPER is also associated with phospholipase $\mathrm{C}$, and the inositol receptor and ryanodine receptor-mediated increase in intracellular calcium $(24,34)$. This commentary is concentrated specifically on the possible rapid effects of GPER in hippocampal-dependent spatial memory function and synaptic plasticity.

Keywords: estrogen, estrogen receptor, GPER, spatial memory, synaptic plasticity 


\section{ROLE OF GPER IN HIPPOCAMPAL-DEPENDENT SPATIAL MEMORY}

In hippocampal neurons, GPER immunoreactivity is associated with the plasma membrane and endoplasmic reticulum, along with axon terminals and dendritic spines (22, 24, 29-31, 35-40). It is well established that estrogen can influence synaptic function and improve memory $(12,41-49)$. G1, a nonsteroidal high-affinity selective GPER agonist, does not bind classical ERs (50), but similar to estrogen, improves cognitive performance, including social recognition, spatial working memory, and long-term spatial memory consolidation (51-59). Results from recent studies by the Frick group, elegantly demonstrate that like 17-beta estradiol (E2), activation of GPER, by direct infusion of G1 into the dorsal hippocampus, can facilitate object recognition memory and hippocampaldependent spatial memory in ovarectimized female mice. The

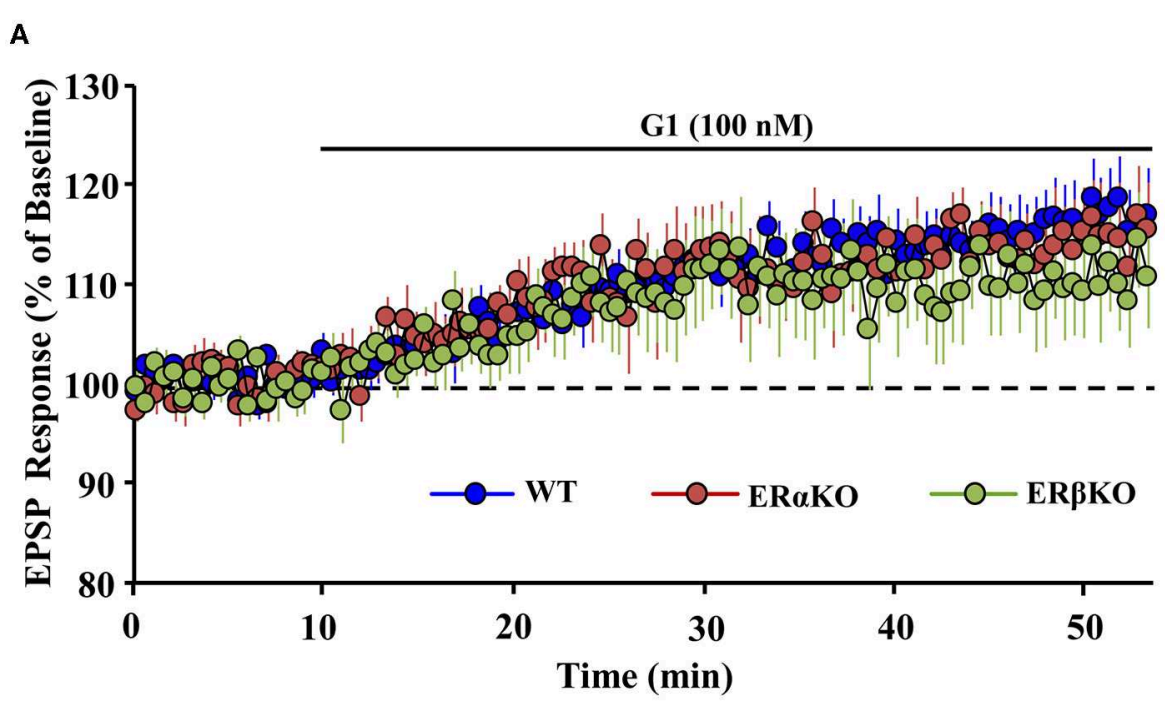

B

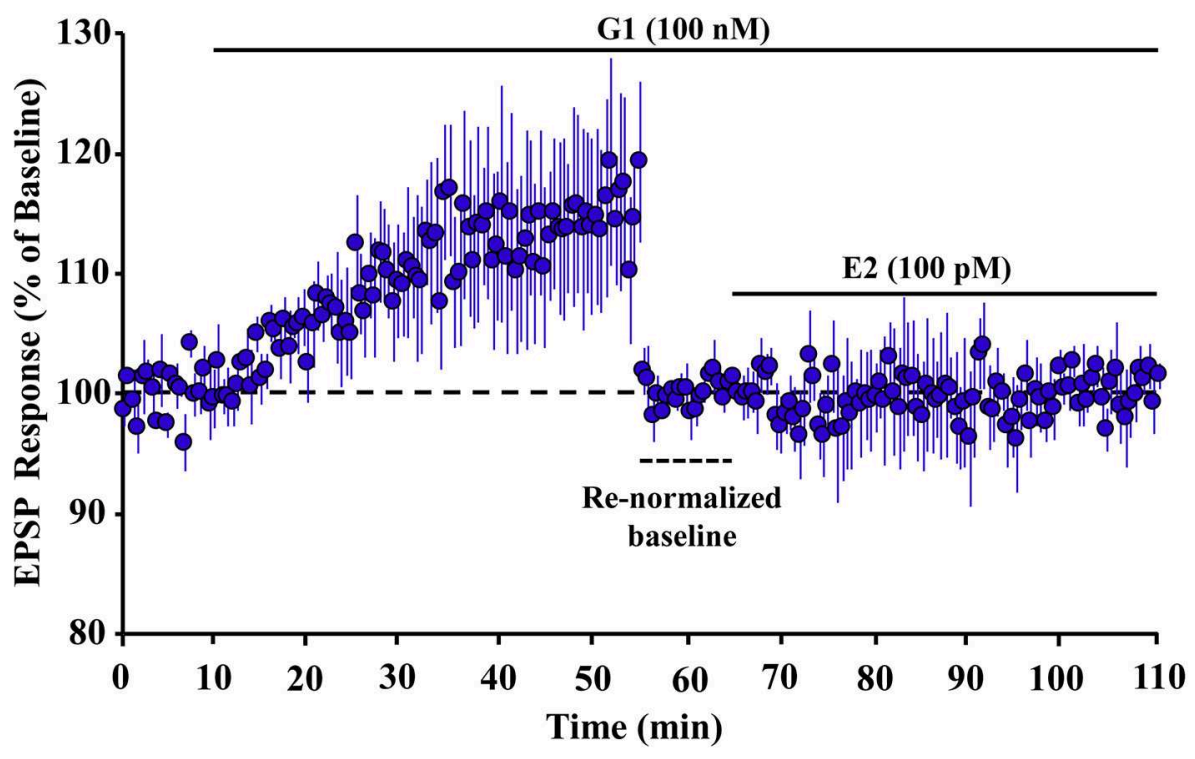

FIGURE 1 | Effect of GPER selective agonist, G1 on hippocampal synaptic responses. (A) Time course of the field EPSP measurements on slices obtained from wild type (WT, blue), estrogen receptor (ER) alpha knockout (ER $\alpha K O$, red), and ER beta knockout (ERßKO, green) mice obtained 10 min before and 45 min after application of G1. (B) G1 blocked the 17-beta estradiol (E2)-induced enhanced synaptic responses in hippocampal slices. Time course of field EPSP measurements obtained from hippocampal slices $10 \mathrm{~min}$ before and $45 \mathrm{~min}$ after $\mathrm{G} 1$ application. Bath application of $\mathrm{G} 1$ significantly enhanced the synaptic response. Baseline was re-normalized from last 10 min recording (dashed line) following the start of G1 application, and E2 was bath applied in the continued presence of G1. E2 in presence of G1 failed to further enhance synaptic response. Adapted from Kumar et al. (11). Copyright permission granted order \# 480097130349. 
enhancement of memory was not due to activation of the extracellular signal-regulated kinase signaling normally observed following E2 treatment. Rather, GPER activation was associated with phosphorylation of c-Jun N-terminal, cofilin-mediated actin polymerization, and spinogenesis in region CA1 (55, 57). Overall, these studies provide strong evidence that like E2, activation of GPER can facilitate hippocampal-dependent memory performance.

\section{GPER AND HIPPOCAMPAL SYNAPTIC FUNCTION}

In addition to enhancing memory performance, GPER activation also contributes to synaptic plasticity. Activation of GPER enhances synaptic transmission at hippocampal CA3-CA1 synapses $(11,54,60,61)$. We recently demonstrated that GPER is a major component of E2-mediated upregulation in extracellular signal-regulated kinase and the rapid facilitation of synaptic responses at CA3-CA1 hippocampal synapses of ovariectomized mice. In addition, the GPER agonist, G1, induced an increase of excitatory postsynaptic potentials (EPSPs) in hippocampal slices obtained from ovariectomized ER alpha knockout $(\mathrm{ER} \alpha \mathrm{KO})$ and ER beta knockout (ER $\beta K O)$ mice (Figure 1A). Confirmation that GPER is a mechanism for rapid E2 effects on synaptic transmission was proven by demonstrating that prior application of G1 blocked the E2-induced enhancement of synaptic responses in hippocampal slices (Figure 1B), while bath application of E2 in absence of G1 increases synaptic responses (11). Interestingly, Oberlander and Woolley demonstrated that GPERinduced potentiation of excitatory synaptic responses in CA1 hippocampal pyramidal neurons is restricted to females and involves postsynaptic mechanisms (61). The role of GPER in synaptic plasticity is still evolving (62-65); however, a number of recent studies indicate that activation of GPER contributes to a rapid increase in hippocampal dendritic spinogenesis and spine density $(11,54,57,60,61,66,67)$.

\section{CONCLUDING STATEMENT}

In many ways, the effects of E2 are opposite to that of aging (3, 68). Recent findings indicate that similar to E2, GPER participates in the rapid effects of the E2-induced increase in hippocampal synaptic transmission and improved cognition. Thus, it will be interesting for future research to explore changes in GPER expression or function over the life span, and their contribution to impaired cognitive and synaptic function associated with aging and neurodegenerative diseases.

\section{DATA AVAILABILITY STATEMENT}

The raw data supporting the conclusions of this article will be made available by the authors, without undue reservation.

\section{ETHICS STATEMENT}

The animal study was reviewed and approved by University of Florida.

\section{AUTHOR CONTRIBUTIONS}

All authors listed have made a substantial, direct and intellectual contribution to the work, and approved it for publication.

\section{ACKNOWLEDGMENTS}

This work was supported by NIH grants AG037984, AG049711, AG052258, and the Evelyn F. McKnight Brain Research Foundation. Special thanks to Dr. Linda Bean for editorial assistance.

\section{REFERENCES}

1. Aenlle KK, Foster TC. Aging alters the expression of genes for neuroprotection and synaptic function following acute estradiol treatment. Hippocampus. (2010) 20:1047-60. doi: 10.1002/hipo. 20703

2. Han X, Aenlle KK, Bean LA, Rani A, Semple-Rowland SL, Kumar A, et al. Role of estrogen receptor alpha and beta in preserving hippocampal function during aging. J Neurosci. (2013) 33:2671-83. doi: 10.1523/JNEUROSCI.4937-12.2013

3. Bean LA, Ianov L, Foster TC. Estrogen receptors, the hippocampus, and memory. Neuroscientist. (2014) 20:534-45. doi: 10.1177/1073858413519865

4. McEwen BS, Alves SE. Estrogen actions in the central nervous system. Endocr Rev. (1999) 20:279-307. doi: 10.1210/er.20.3.279

5. Pietras RJ, Levin ER, Szego CM. Estrogen receptors and cell signaling. Science. (2005) 310:51-3; author reply 51-3. doi: 10.1126/science.310.5745.51

6. Li R, Cui J, Shen Y. Brain sex matters: estrogen in cognition and alzheimer's disease. Mol Cell Endocrinol. (2014) 389:1321. doi: 10.1016/j.mce.2013.12.018

7. Li R, Singh M. Sex differences in cognitive impairment and alzheimer's disease. Front Neuroendocrinol. (2014) 35:385-403. doi: 10.1016/j.yfrne.2014.01.002

8. Kelly MJ, Levin ER. Rapid actions of plasma membrane estrogen receptors. Trends Endocrinol Metab. (2001) 12:1526. doi: 10.1016/S1043-2760(01)00377-0

9. Spencer JL, Waters EM, Romeo RD, Wood GE, Milner TA, McEwen BS. Uncovering the mechanisms of estrogen effects on hippocampal function. Front Neuroendocrinol. (2008) 29:219-37. doi: 10.1016/j.yfrne.2007.08.006

10. Fugger HN, Kumar A, Lubahn DB, Korach KS, Foster TC. Examination of estradiol effects on the rapid estradiol mediated increase in hippocampal synaptic transmission in estrogen receptor alpha knockout mice. Neurosci Lett. (2001) 309:207-9. doi: 10.1016/S0304-3940(01)02083-3

11. Kumar A, Bean LA, Rani A, Jackson T, Foster TC. Contribution of estrogen receptor subtypes, eRalpha, eRbeta, and gPER1 in rapid estradiol-mediated enhancement of hippocampal synaptic transmission in mice. Hippocampus. (2015) 25:1556-66. doi: 10.1002/hipo.22475

12. Bean LA, Kumar A, Rani A, Guidi M, Rosario AM, Cruz PE, et al. Re-Opening the critical window for estrogen therapy. J Neurosci. (2015) 35:1607793. doi: 10.1523/JNEUROSCI.1890-15.2015

13. Tuscher JJ, Taxier LR, Schalk JC, Haertel JM, Frick KM. Chemogenetic suppression of medial prefrontal-Dorsal hippocampal interactions prevents estrogenic enhancement of memory consolidation in female mice. eNeuro. (2019) 6:18. doi: 10.1523/ENEURO.0451-18.2019 
14. Foster TC. Interaction of rapid signal transduction cascades and gene expression in mediating estrogen effects on memory over the life span. Front Neuroendocrinol. (2005) 26:51-64. doi: 10.1016/j.yfrne.2005.04.004

15. Carmeci C, Thompson DA, Ring HZ, Francke U, Weigel RJ. Identification of a gene (GPR30) with homology to the g-protein-coupled receptor superfamily associated with estrogen receptor expression in breast cancer. Genomics. (1997) 45:607-17. doi: 10.1006/geno.1997.4972

16. Feng Y, Gregor P. Cloning of a novel member of the g protein-coupled receptor family related to peptide receptors. Biochem Biophys Res Commun. (1997) 231:651-4. doi: 10.1006/bbrc.1997.6161

17. Kvingedal AM, Smeland EB. A novel putative g-protein-coupled receptor expressed in lung, heart and lymphoid tissue. FEBS letters. (1997) 407:5962. doi: 10.1016/S0014-5793(97)00278-0

18. O’Dowd BF, Nguyen T, Marchese A, Cheng R, Lynch KR, Heng HH, et al. Discovery of three novel g-protein-coupled receptor genes. Genomics. (1998) 47:310-3. doi: 10.1006/geno.1998.5095

19. Owman C, Blay P, Nilsson C, Lolait SJ. Cloning of human cDNA encoding a novel heptahelix receptor expressed in burkitt's lymphoma and widely distributed in brain and peripheral tissues. Biochem Biophys Res Commun. (1996) 228:285-92. doi: 10.1006/bbrc.1996.1654

20. Takada Y, Kato C, Kondo S, Korenaga R, Ando J. Cloning of cDNAs encoding g protein-coupled receptor expressed in human endothelial cells exposed to fluid shear stress. Biochem Biophys Res Commun. (1997) 240:73741. doi: 10.1006/bbrc. 1997.7734

21. Alexander SP, Benson HE, Faccenda E, Pawson AJ, Sharman JL, McGrath JC, et al. The Concise Guide to PHARMACOLOGY 2013/14: overview. Br J Pharmacol. (2013) 170:1449-58. doi: 10.1111/bph.12444

22. Funakoshi T, Yanai A, Shinoda K, Kawano MM, Mizukami Y. G proteincoupled receptor 30 is an estrogen receptor in the plasma membrane. Biochem Biophys Res Commun. (2006) 346:904-10. doi: 10.1016/j.bbrc.2006.05.191

23. Filardo EJ, Quinn JA, Bland KI, Frackelton AR Jr, estrogen-induced activation of erk-1 and erk-2 requires the g protein-coupled receptor homolog, gPR30, and occurs via trans-activation of the epidermal growth factor receptor through release of hB-EGF. Mol Endocrinol. (2000) 14:164960. doi: $10.1210 /$ mend.14.10.0532

24. Revankar CM, Cimino DF, Sklar LA, Arterburn JB, Prossnitz ER. A transmembrane intracellular estrogen receptor mediates rapid cell signaling. Science. (2005) 307:1625-30. doi: 10.1126/science.1106943

25. Barton M, Filardo EJ, Lolait SJ, Thomas P, Maggiolini M, Prossnitz ER. Twenty years of the G protein-coupled estrogen receptor GPER: historical and personal perspectives. J Steroid Biochem Mol Biol. (2018) 176:415. doi: 10.1016/j.jsbmb.2017.03.021

26. Alexander A, Irving AJ, Harvey J. Emerging roles for the novel estrogensensing receptor GPER1 in the CNS. Neuropharmacology. (2017) 113:65260. doi: 10.1016/j.neuropharm.2016.07.003

27. Prossnitz ER, Arterburn JB, Smith HO, Oprea TI, Sklar LA, Hathaway HJ. Estrogen signaling through the transmembrane G protein-coupled receptor GPR30. Annu Rev Physiol. (2008) 70:165-90. doi: 10.1146/annurev.physiol.70.113006.100518

28. Prossnitz ER, Arterburn JB. International union of basic and clinical pharmacology. XCVII. G protein-coupled estrogen receptor and its pharmacologic modulators. Pharmacol Rev. (2015) 67:505-40. doi: 10.1124/pr.114.009712

29. Srivastava DP, Evans PD. G-protein oestrogen receptor 1: trials and tribulations of a membrane oestrogen receptor. J Neuroendocrinol. (2013) 25:1219-30. doi: 10.1111/jne.12071

30. Brailoiu E, Dun SL, Brailoiu GC, Mizuo K, Sklar LA, Oprea TI, et al. Distribution and characterization of estrogen receptor g protein-coupled receptor 30 in the rat central nervous system. J Endocrinol. (2007) 193:31121. doi: 10.1677/JOE-07-0017

31. Hammond R, Nelson D, Gibbs RB. GPR30 co-localizes with cholinergic neurons in the basal forebrain and enhances potassium-stimulated acetylcholine release in the hippocampus. Psychoneuroendocrinology. (2011) 36:182-92. doi: 10.1016/j.psyneuen.2010.07.007

32. Filardo EJ, Thomas P. Minireview: g protein-coupled estrogen receptor1, gPER-1: its mechanism of action and role in female reproductive cancer, renal and vascular physiology. Endocrinology. (2012) 153:295362. doi: $10.1210 /$ en.2012-1061
33. Prossnitz ER, Barton M. The g-protein-coupled estrogen receptor gPER in health and disease. Nat Rev Endocrinol. (2011) 7:715-26. doi: 10.1038/nrendo.2011.122

34. Ariazi EA, Brailoiu E, Yerrum S, Shupp HA, Slifker MJ, Cunliffe HE, et al. The g protein-coupled receptor gPR30 inhibits proliferation of estrogen receptor-positive breast cancer cells. Cancer Res. (2010) 70:118494. doi: 10.1158/0008-5472.CAN-09-3068

35. Matsuda K, Sakamoto H, Mori H, Hosokawa K, Kawamura A, Itose M, et al. Expression and intracellular distribution of the $\mathrm{g}$ protein-coupled receptor 30 in rat hippocampal formation. Neurosci Lett. (2008) 441:949. doi: 10.1016/j.neulet.2008.05.108

36. Filardo E, Quinn J, Pang Y, Graeber C, Shaw S, Dong J, et al. Activation of the novel estrogen receptor g protein-coupled receptor $30(\mathrm{GPR} 30)$ at the plasma membrane. Endocrinology. (2007) 148:3236-45. doi: 10.1210/en.2006-1605

37. Hazell GG, Yao ST, Roper JA, Prossnitz ER, O’Carroll AM, Lolait SJ. Localisation of gPR30, a novel g protein-coupled oestrogen receptor, suggests multiple functions in rodent brain and peripheral tissues. J Endocrinol. (2009) 202:223-36. doi: 10.1677/JOE-09-0066

38. Prossnitz ER, Maggiolini M. Mechanisms of estrogen signaling and gene expression via gPR30. Mol Cell Endocrinol. (2009) 308:32-8. doi: 10.1016/j.mce.2009.03.026

39. Akama KT, Thompson LI, Milner TA, McEwen BS. Post-synaptic density95 (PSD-95) binding capacity of g-protein-coupled receptor 30 (GPR30), an estrogen receptor that can be identified in hippocampal dendritic spines. J Biol Chem. (2013) 288:6438-50. doi: 10.1074/jbc.M112.412478

40. Waters EM, Thompson LI, Patel P, Gonzales AD, Ye HZ, Filardo EJ, et al. Gprotein-coupled estrogen receptor 1 is anatomically positioned to modulate synaptic plasticity in the mouse hippocampus. J Neurosci. (2015) 35:238497. doi: 10.1523/JNEUROSCI.1298-14.2015

41. Woolley CS, Gould E, Frankfurt M, McEwen BS. Naturally occurring fluctuation in dendritic spine density on adult hippocampal pyramidal neurons. J Neurosci. (1990) 10:40359. doi: 10.1523/JNEUROSCI.10-12-04035.1990

42. Woolley CS, McEwen BS. Estradiol mediates fluctuation in hippocampal synapse density during the estrous cycle in the adult rat. J Neurosci. (1992) 12:2549-54. doi: 10.1523/JNEUROSCI.12-07-02549.1992

43. Inagaki T, Frankfurt M, Luine V. Estrogen-induced memory enhancements are blocked by acute bisphenol a in adult female rats: role of dendritic spines. Endocrinology. (2012) 153:3357-67. doi: 10.1210/en.2012-1121

44. Mukai H, Tsurugizawa T, Murakami G, Kominami S, Ishii H, Ogiue-Ikeda M, et al. Rapid modulation of long-term depression and spinogenesis via synaptic estrogen receptors in hippocampal principal neurons. J Neurochem. (2007) 100:950-67. doi: 10.1111/j.1471-4159.2006.04264.x

45. Phan A, Lancaster KE, Armstrong JN, MacLusky NJ, Choleris E. Rapid effects of estrogen receptor alpha and beta selective agonists on learning and dendritic spines in female mice. Endocrinology. (2011) 152:1492502. doi: 10.1210/en.2010-1273

46. Phan A, Suschkov S, Molinaro L, Reynolds K, Lymer JM, Bailey CD, et al. Rapid increases in immature synapses parallel estrogen-induced hippocampal learning enhancements. Proc Natl Acad Sci USA. (2015) 112:16018-23. doi: 10.1073/pnas.1522150112

47. Tuscher JJ, Luine V, Frankfurt M, Frick KM. Estradiol-Mediated spine changes in the dorsal hippocampus and medial prefrontal cortex of ovariectomized female mice depend on eRK and mTOR activation in the dorsal hippocampus. J Neurosci. (2016) 36:1483-9. doi: 10.1523/JNEUROSCI.3135-15.2016

48. Tuscher JJ, Szinte JS, Starrett JR, Krentzel AA, Fortress AM, Remage-Healey $\mathrm{L}$, et al. Inhibition of local estrogen synthesis in the hippocampus impairs hippocampal memory consolidation in ovariectomized female mice. Horm Behav. (2016) 83:60-7. doi: 10.1016/j.yhbeh.2016.05.001

49. Foster TC, Rani A, Kumar A, Cui L, Semple-Rowland SL. Viral vectormediated delivery of estrogen receptor-alpha to the hippocampus improves spatial learning in estrogen receptor-alpha knockout mice. Mol Ther. (2008) 16:1587-93. doi: 10.1038/mt.2008.140

50. Bologa CG, Revankar CM, Young SM, Edwards BS, Arterburn JB, Kiselyov AS, et al. Virtual and biomolecular screening converge on a selective agonist for gPR30. Nat Chem Biol. (2006) 2:207-12. doi: 10.1038/nchembio775

51. Hammond R, Mauk R, Ninaci D, Nelson D, Gibbs RB. Chronic treatment with estrogen receptor agonists restores acquisition of a spatial 
learning task in young ovariectomized rats. Horm Behav. (2009) 56:30914. doi: 10.1016/j.yhbeh.2009.06.008

52. Hammond R, Nelson D, Kline E, Gibbs RB. Chronic treatment with a gPR30 antagonist impairs acquisition of a spatial learning task in young female rats. Horm Behav. (2012) 62:367-74. doi: 10.1016/j.yhbeh.2012.07.004

53. Hawley WR, Grissom EM, Moody NM, Dohanich GP, Vasudevan N. Activation of g-protein-coupled receptor 30 is sufficient to enhance spatial recognition memory in ovariectomized rats. Behav Brain Res. (2014) 262:6873. doi: 10.1016/j.bbr.2014.01.006

54. Gabor C, Lymer J, Phan A, Choleris E. Rapid effects of the gprotein coupled oestrogen receptor (GPER) on learning and dorsal hippocampus dendritic spines in female mice. Physiol Behav. (2015) 149:5360. doi: 10.1016/j.physbeh.2015.05.017

55. Kim J, Szinte JS, Boulware MI, Frick KM. 17 beta-estradiol and agonism of G-protein-coupled estrogen receptor enhance hippocampal memory via different cell-signaling mechanisms. J Neurosci. (2016) 36:330921. doi: 10.1523/JNEUROSCI.0257-15.2016

56. Lymer J, Robinson A, Winters BD, Choleris E. Rapid effects of dorsal hippocampal g-protein coupled estrogen receptor on learning in female mice. Psychoneuroendocrinology. (2017) 77:131-40. doi: 10.1016/j.psyneuen.2016.11.019

57. Kim J, Schalk JC, Koss WA, Gremminger RL, Taxier LR, Gross KS, et al. Dorsal hippocampal actin polymerization is necessary for activation of g-protein-Coupled estrogen receptor (GPER) to increase cAl dendritic spine density and enhance memory consolidation. J Neurosci. (2019) 39:9598-610. doi: 10.1523/JNEUROSCI.2687-18.2019

58. Machado GDB, de Freitas BS, Florian LZ, Monteiro RT, Gus H, Schroder N. G protein-coupled oestrogen receptor stimulation ameliorates iron- and ovariectomy-induced memory impairments through the cAMP/PKA/CREB signalling pathway. J Neuroendocrinol. (2019) 31:e12780. doi: 10.1111/jne.12780

59. Ervin KS, Phan A, Gabor CS, Choleris E. Rapid oestrogenic regulation of social and nonsocial learning. J Neuroendocrinol. (2013) 25:111632. doi: 10.1111/jne.12079

60. Lebesgue D, Traub M, De Butte-Smith M, Chen C, Zukin RS, Kelly MJ, et al. Acute administration of non-classical estrogen receptor agonists attenuates ischemia-induced hippocampal neuron loss in middle-aged female rats. PLoS ONE. (2010) 5:e8642. doi: 10.1371/journal.pone.0008642
61. Oberlander JG, Woolley CS. 17beta-Estradiol Acutely Potentiates glutamatergic synaptic transmission in the hippocampus through distinct mechanisms in males and females. J Neurosci. (2016) 36:2677-90. doi: 10.1523/JNEUROSCI.4437-15.2016

62. Briz V, Baudry M. Estrogen regulates protein synthesis and actin polymerization in hippocampal neurons through different molecular mechanisms. Front Endocrinol (Lausanne). (2014) 5:22. doi: 10.3389/fendo.2014.00022

63. Briz V, Liu Y, Zhu G, Bi X, Baudry M. A novel form of synaptic plasticity in field cA3 of hippocampus requires GPER1 activation and BDNF release. J Cell Biol. (2015) 210:1225-37. doi: 10.1083/jcb.201504092

64. Wang W, Le AA, Hou B, Lauterborn JC, Cox CD, Levin ER, et al. MemoryRelated synaptic plasticity is sexually dimorphic in rodent hippocampus. J Neurosci. (2018) 38:7935-51. doi: 10.1523/JNEUROSCI.0801-18.2018

65. Xu W, Cao J, Zhou Y, Wang L, Zhu G. GPR30 activation improves memory and facilitates dHPG-induced ITD in the hippocampal cA3 of middleaged mice. Neurobiol Learn Mem. (2018) 149:10-9. doi: 10.1016/j.nlm.2018. 02.005

66. Bian C, Zhu H, Zhao Y, Cai W, Zhang J. Intriguing roles of hippocampussynthesized 17beta-estradiol in the modulation of hippocampal synaptic plasticity. J Mol Neurosci. (2014) 54:271-81. doi: 10.1007/s12031-0140285-8

67. Frick KM. Molecular mechanisms underlying the memory-enhancing effects of estradiol. Horm Behav. (2015) 74:4-18. doi: 10.1016/j.yhbeh.2015.05.001

68. Foster TC. Role of estrogen receptor alpha and beta expression and signaling on cognitive function during aging. Hippocampus. (2012) 22:65669. doi: 10.1002/hipo.20935

Conflict of Interest: The authors declare that the research was conducted in the absence of any commercial or financial relationships that could be construed as a potential conflict of interest.

Copyright (c) 2020 Kumar and Foster. This is an open-access article distributed under the terms of the Creative Commons Attribution License (CC BY). The use, distribution or reproduction in other forums is permitted, provided the original author(s) and the copyright owner(s) are credited and that the original publication in this journal is cited, in accordance with accepted academic practice. No use, distribution or reproduction is permitted which does not comply with these terms. 